\title{
A bibliometric study of publication patterns in rational use of medicines in Iran
}

\author{
Sarah MOUSAVI, Ava MANSOURI, Alireza AHMADVAND. \\ Received (first version): 1-Aug-2012 Accepted: 9-Feb-2013
}

\begin{abstract}
*
Background: Inappropriate use of drugs is commonly observed in health care system throughout the world especially in developing countries. The consequences of irrational use of drugs are enormous for patients and communities. Proper interventions would have important financial and public health benefits. Several studies have been performed about rational use of drugs in Iran. Objective: The objective of this study was to assess scientific output on rational use of drugs in Iran using a bibliometric analysis of publications. Methods: A systematic search was conducted for finding all papers (English and Persian) using Pubmed, Web of Science, Google Scholar, CINAHL, Proquest, International Pharmaceutical Abstract and Persian databases including SID, Iran Medex and Maglran. Retrieved articles were categorized by research topics and year of publication. Impact Factor of the journals, citation analysis of first authors, most cited topics and average citations per item were analyzed. Results: A total of 668 articles were retrieved from all search engines after excluding irrelevant, 466 articles were included in the review. Number of publications increased dramatically after 2001(more than 10 times). Evaluation of prescribing pattern (15\%), self-medication (11.3\%) and adverse drug reaction $(9.1 \%)$ were among the most studied topics. From the total of 165 journals, 60 of them had Impact factors and 125 articles were published in these journals. Antimicrobial resistance and adverse drug reaction were the most cited topic. Conclusion: Publication of articles on rational use of drugs research in Iran has undergone an important increase during last decade. Further analysis of research outputs is necessary to achieve rational use of medicines goal.
\end{abstract}

Keywords: Drug Utilization; Bibliometrics; Iran

\footnotetext{
"Sarah MOUSAVI. Clinical Pharmacy Department, Faculty of Pharmacy and Research Center for Rational Use of Drugs, Tehran University of Medical Sciences. Tehran (Iran).

Ava MANSOURI. Research Center for Rational Use of Drugs, Tehran University of Medical Sciences. Tehran (Iran).

Alireza AHMADVAND. Research Center for Rational Use of Drugs, Tehran University of Medical Sciences. Tehran (Iran).
}

\author{
ESTUDIO BIBLIOMÉTRICO DE LOS \\ PATRONES DE PUBLICACIÓN EN USO \\ RACIONAL DE MEDICAMENTOS EN IRÁN
}

\section{RESUMEN}

Antecedentes: El uso inapropiado de medicamentos es frecuentemente observado en el sistema sanitario en todo el mundo, especialmente en países desarrollados. Las consecuencias del uso irracional de medicamento son enormes para los pacientes y la comunidad. Intervenciones adecuadas podrían tener importantes beneficios financieros y de salud pública. Se han realizado diversos estudios sobre el uso racional de medicamentos en Irán.

Objetivo: el objetivo de este estudio fue evaluar la producción científica sobre uso racional de medicamentos en Irán utilizando un análisis bibliométrico de las publicaciones.

Métodos: Se realizó una búsqueda sistemática localizando todos los artículos (inglés y persa) usando Pubmed, Web of Science, Google Scholar, CINAHL, Proquest, International Pharmaceutical Abstracts, y bases de datos persas como SID, Iran Medex and MagIran. Los artículos recuperados se clasificaron por temas de investigación y año de publicación. Se analizaron los factores de impacto de las revistas, las citaciones de los primeros autores, los asuntos más citados, y la media de citaciones por ítem.

Resultados: Se recuperaron un total de 668 artículos de todos los motores de búsqueda, después de excluir los irrelevantes se incluyeron en la revisión 466 artículos. El número de publicaciones se incrementó dramáticamente después de 2001 (más de 10 veces). Entre los asuntos más estudiados estaban la evaluación de los patrones de prescripción (15\%), la automedicación (11,3\%) y las reacciones adversas (9,1\%). Del total de 165 revistas, 60 tenían factor de impacto y se publicaron 125 artículos en estas revistas. Las resistencias a antimicrobianos y las reacciones adversas fueron los asuntos más citados.

Conclusión: La publicación de artículos sobre el uso racional de medicamentos en Irán ha experimentado un incremento importante en la última década. Se necesitan más análisis de los resultados de la investigación para alcanzar la meta del uso racional de medicamentos.

Palabras clave: Utilización de Medicamentos; Bibliometría; Irán 


\section{INTRODUCTION}

In 1978, the declaration of Alma Ata identified the quality, rational use and provision of essential medicines as one of the eight key component of primary health care. ${ }^{1}$ During the 1985 conference of Experts on Rational Use of Drugs in Nairobi, the modern definition of rational use of medicines was stated "Rational use of medicines require that patients receive medications based on their clinical needs, in doses that meet their requirements, for an adequate period of time and at the lowest possible cost for patients and their community". ${ }^{2}$ Inappropriate, ineffective and economically inefficient use of drugs commonly occurs at health facilities in both developing and developed countries. $^{3-5}$ More than $50 \%$ of all medicines worldwide are prescribed, dispensed or sold inappropriately and $50 \%$ of patients fail to take them correctly. ${ }^{6}$ Irrational use of drugs result in increased and unsafe treatment, increased adverse drug reaction, accelerated rate of antimicrobial resistance and higher costs of treatment. ${ }^{7}$

Since the 1976 revolution, the National Drug Policy (NDP) in Iran has been based on using generic medications, local production of generic medicines, price control, self-sufficiency in biological products and active good manufacturing practice inspection. About 4200 medicines including chemical, herbal and biological dosage forms covering over 2400 drug entities on the National Drug List have been registered and granted marketing authorization. About $95 \%$ of drugs (in term of volume) on the market in Iran have been produced by close the 70 pharmaceutical companies. ${ }^{8}$ Essential drugs are estimated to be available and affordable for more than $90 \%$ of the population. ${ }^{9}$

The Iranian ministry of health has established a center for promoting rational use of drugs in 1995 and dedicated considerable financial and human resources to monitoring rational use of drugs. Despite these successes, inappropriate use of drugs in terms of non-adherence to prescribed drugs, overuse and misuse of antibiotics and injectable drugs and use of unnecessary expensive drugs, remain a problem and require prompt attention. 8,10

Several studies were performed in Iran about rational use of drugs. Review of these studies help to obtain information about the current state of research, measure existing practice and find gaps. This allows researchers to identify and undertake new lines of research and help policy makers to evaluate and imply strategies to improve rational use of drugs. Bibliometric analysis is a useful tool for obtaining information about scientific activity in a certain field of area. Bibliometrics look at publication patterns in research areas using quantitative analysis and statistics to analyze citation data.

The objective of this study was to perform bibliographic and bibliometric analyses of publications related to rational use of drugs in Iran and assess the state of rational use of drugs research.

\section{METHODS}

In order to provide enough databases about the subject, we did a systematic search utilizing both English and Persian electronic database. PubMed, Web of Science, International Pharmaceutical Abstracts (IPA), CINAHL, ProQuest and Google Scholar were searched. Persian electronic database included were Mag Iran, Iran Medex and SID.

English database were searched using keywords included terms describing and covering all fields in rational use of drugs. Search terms were mapped

\begin{tabular}{|c|c|c|}
\hline $\begin{array}{ll}\text { - } & \text { Administrative personnel } \\
\text { - } & \text { Adverse Drug reaction reporting } \\
\text { - } & \text { Behavioral medicine } \\
\text { - } & \text { Clinical Pharmacy information } \\
\text { - } & \text { Community Pharmacy service } \\
\text { - } & \text { Cost -benefit analysis } \\
\text { - } & \text { Costs and cost analysis } \\
\text { - } & \text { Drug costs } \\
\text { - } & \text { Drug information services } \\
\text { - } & \text { Drug interactions } \\
\text { - } & \text { Drug monitoring } \\
\text { - } & \text { Drug resistance, Microbial antibiotic } \\
\text { - } & \text { Drug resistance, microbial bacterial } \\
\text { - } & \text { Drug therapy } \\
\text { - } & \text { Drug users } \\
\text { - } & \text { Drug utilization } \\
\text { - } & \text { Drug utilization review } \\
\text { - } & \text { Economics pharmaceutical } \\
\text { - } & \text { Economics, pharmaceutical } \\
\text { - } & \text { Education, Pharmacy } \\
\text { - } & \text { Education, Pharmacy, continuing } \\
\text { - } & \text { Education, Pharmacy, Graduate } \\
\text { - } & \text { Fees, Pharmaceutical } \\
\text { - } & \text { Guideline } \\
\text { - } & \text { Guideline adherence }\end{array}$ & $\begin{array}{ll}\text { - } & \text { Health care quality, Access and Evaluation } \\
\text { - } & \text { Health knowledge, Attitudes and practice } \\
\text { - } & \text { Health knowledge, attitudes, practice } \\
\text { - } & \text { Health status indicators } \\
\text { - } & \text { Hospital costs } \\
\text { - } & \text { Inappropriate Prescribing } \\
\text { - } & \text { Insurance, pharmaceutical services } \\
\text { - } & \text { Medication adherence } \\
\text { - } & \text { Medication errors } \\
\text { - } & \text { Medication reconciliation } \\
\text { - } & \text { Medication system } \\
\text { - } & \text { Medication systems, hospital } \\
\text { - } & \text { Medication systems, Hospital } \\
\text { - } & \text { Medication therapy management } \\
\text { - } & \text { Non Prescriptions Drugs } \\
\text { - } & \text { Off -label use } \\
\text { - } & \text { Patient acceptance of health care } \\
\text { - } & \text { Pharmaceutical services } \\
\text { - } & \text { Pharmaceutical services } \\
\text { - } & \text { Pharmacies } \\
\text { - } & \text { Pharmacoepidemiology } \\
\text { - } & \text { Pharmacy } \\
\text { - } & \text { Pharmacy administration } \\
\text { - } & \text { Pharmacy and therapeutics committee }\end{array}$ & $\begin{array}{ll}\text { - } & \text { Policy making } \\
\text { - } & \text { Poly pharmacy } \\
\text { - } & \text { Pharmacy service, Hospital } \\
\text { - } & \text { Practice guideline Publication- types } \\
\text { - } & \text { Prescriptions } \\
\text { - } & \text { Prescriptions Drug } \\
\text { - } & \text { Quality indicator, Health care } \\
\text { - } & \text { Safety -based drug with drawls } \\
\text { - } & \text { School, Pharmacy } \\
\text { - } & \text { Self-Medication } \\
\text { - } & \text { Student, Pharmacy }\end{array}$ \\
\hline
\end{tabular}




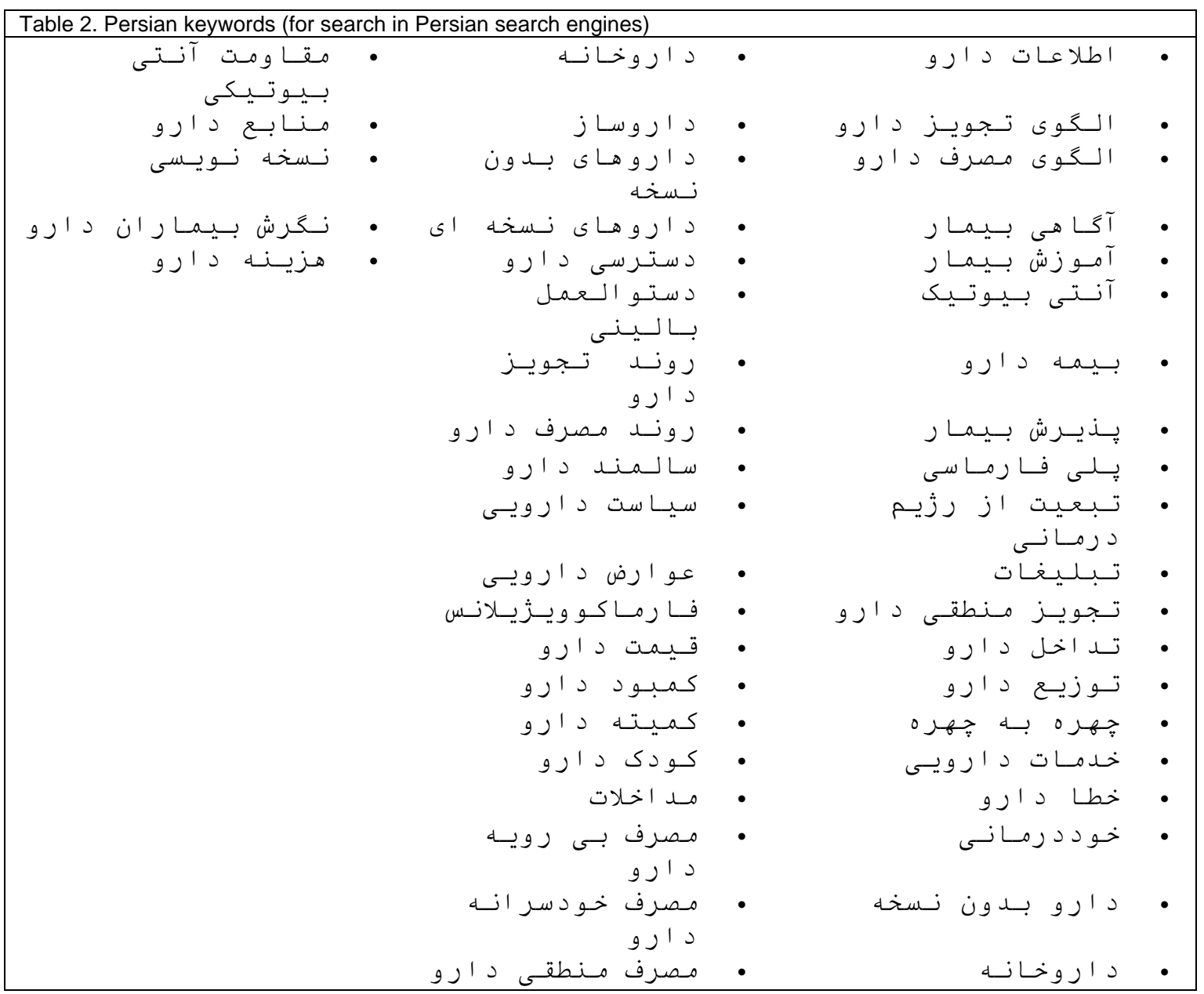

on to MeSH terms in PubMed (Table 1). All keywords were combined with "Iran" and all database searched in all fields without narrowing or limiting search elements to find the most relevant literatures about the subject.

The keywords translated to Persian and Persian database were searched using these keywords in all fields without limiting search elements (Table 2). Both English and Persian database were searched till February 2012.

The title and abstract of the documents retrieved were examined to identify most relevant articles and omit irrelevant or duplicate papers (articles evaluate the different aspect of rational use of drugs such as self-medication, drug usage evaluation, adverse drug reaction were included, but those were evaluated for example the efficacy of drugs were excluded). The selection was made independently by two reviewers, any disagreement about inclusion or exclusion of a specific article was resolved by a third reviewer.

The articles retrieved were entered into a Microsoft office Access 2007 (Microsoft Corporation, Redmond, WA). The variables registered for each article were: First author, year of publication, year of study, journal title, design and area of study, type of population, health-care setting, city, topics or subjects and primary and secondary outcomes of the study.
For data analysis the Access database were exported into Microsoft excel 2007 (Microsoft Corporation, Redmond, WA). We analyzed number of publication and publication topics for the retrieved articles. The Impact Factor of the journals in which the articles were published was studied. The latest Impact Factors in 2011 were reported. Other journals were categorized based on indexing in PubMed, Scopus, Web of Science, Ebsco and other sites. Citation analysis of authors who had more than 4 related articles was evaluated. Most cited topic and average citations per item and total citation were reported.

We conducted descriptive analyses of key descriptive study variables. The analyses were summarized in tables and figures.

\section{RESULTS}

A total of 980 publications were resulted from all search engines. All duplicates were excluded, resulting in 668 publications (144 Persian and 528 English articles). Out of all the complete articles that were retrieved and valuated, 202 articles were found to have no relevant data about rational use of drugs, and the remaining (466 articles) were exported to Excel database and analyzed.

Figure 1 shows the number of publications per 1 year period. There was an increasing trend in the number of publications from 4 articles in period 
1975-1994 to more than 170 articles in 2010-2012. More than half of the studies' design were crosssectional $(n=328,72.9 \%)$, less than $9 \%(n=40)$ of studies including trials (Randomized Controlled Trials).

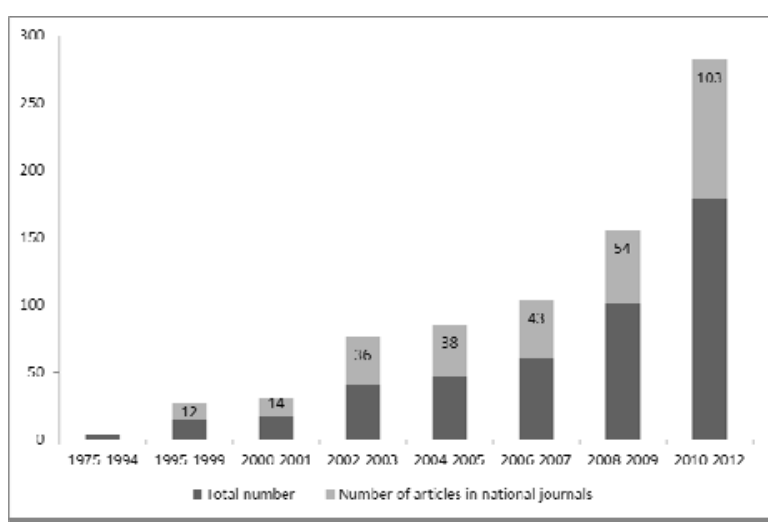

Figure 1. Number or publications

The analysis of topics showed that most studies $(n=68)(15 \%)$ were focused on evaluation of prescribing pattern, $(n=51)(11.3 \%)$, self-medication $(\mathrm{n}=41)(9.1 \%)$ and adverse drug reaction (Table 3$)$. Less than $3.3 \% \quad(n=15)$ of studies were about clinical guidelines implementation and drug usage evaluation. Few studies were focused on policy making, health insurance and cost analysis.

Table 4 and Table 5 show the setting of studies and type of population. Hospitals $(n=171)(43.3 \%)$ and patients $(n=192)(43.9 \%)$ were the most studied setting and groups. Most of the studies were performed in Tehran $(n=198)$ and Esfahan $(n=34)$ (the two most crowded city in Iran).

Table 6 and 7 shows the distribution of articles and impact factor of the journals. Sixty journals have impact factors and 91 journals were indexed in PubMed, Scopus, Web of science or others. Of the entire article retrieved, 125 of them were published in journals with impact factors and 193 in journals that were indexing in mentioned sites above. Other journals had no impact factor and were just being indexed in Persian sites such as SID, Mag Iran or Iran Medex. From all the journals, 47 of them were

\begin{tabular}{|l|l|}
\hline Table 3. Study topics. & $15.0 \%$ \\
\hline Prescribing and dispensing patterns & $11.3 \%$ \\
\hline Self-medication & $9.1 \%$ \\
\hline Adverse drug reactions & $8.4 \%$ \\
\hline Antibacterial resistance & $7.3 \%$ \\
\hline Prescription evaluation & $6.6 \%$ \\
\hline Medication error & $6.0 \%$ \\
\hline Educational intervention & $4.4 \%$ \\
\hline Drug interactions & $4.4 \%$ \\
\hline Compliance & $4.4 \%$ \\
\hline Knowledge Attitude \& Practice & $4.0 \%$ \\
\hline Alternative medicine & $3.8 \%$ \\
\hline Drug Use Evaluation & $3.3 \%$ \\
\hline Standard Treatment Guideline & $2.4 \%$ \\
\hline Cost analysis & $2.0 \%$ \\
\hline Policy making & $1.3 \%$ \\
\hline Health insurance & $1.3 \%$ \\
\hline Over-the-counter drugs & $1.1 \%$ \\
\hline Polypharmacy & $0.4 \%$ \\
\hline Counterfeit medicine & $3.3 \%$ \\
\hline Others & \\
\hline
\end{tabular}

\begin{tabular}{|c|c|}
\hline Hospital & $43.3 \%$ \\
\hline Community & $21.5 \%$ \\
\hline Pharmacy & $9.1 \%$ \\
\hline Clinic* & $3.5 \%$ \\
\hline University & $2.5 \%$ \\
\hline Primary health care & $2.5 \%$ \\
\hline Others & $3.0 \%$ \\
\hline
\end{tabular}

in Persian language and 113 journals in English, 88 of the articles were published in national English journals.

Ten of the main authors had more than 4 articles related to rational use of drugs. The most cited topic of these authors and $\mathrm{H}$-index, average citation per item and total citation of them were summarized in Table 8.

Table 9 shows the total citations and ratios of 6 studied topics. Antimicrobial resistance and adverse drug reaction were the most cited topics.

\section{DISCUSSION}

Publication of articles on rational use of drugs in Iran increased dramatically (more than 10 times from 2000 to 2011) during last decade. But much still remain undone in this field.

Mesgarpour et al. ${ }^{12}$ evaluated the Iranian trend of research in pharmaceutical sciences published in international publication compared to Middle East and North Africa. The results of this study indicated that during 11 years period (1996-2006), Iran stand on the first place of science production within the field of pharmaceutical sciences (mostly pharmacology, toxicology and medicinal chemistry). More than 4000 articles were indexed in Web of Science (ISI), Scopus and IPA during 1996-2006; However the mentioned article did not evaluate rational use of drugs papers but according to our results, publication of about 440 articles on rational use of drugs during a 30 year period (1975-2012) represented a low rate of production compared with the rate of production in other field of pharmaceutical sciences.

Most studies carried out in rational use of drugs are descriptive and there is a lack of analytical studies, particularly those involving controlled randomized trial. The research topics and approaches are

\begin{tabular}{|l|c|}
\hline Table 5. Study population. \\
\hline Patients & $43.9 \%$ \\
\hline Physicians & $12.8 \%$ \\
\hline Pharmacists & $7.8 \%$ \\
\hline Nurses & $7.8 \%$ \\
\hline Normal population & $5.0 \%$ \\
\hline Children & $4.8 \%$ \\
\hline Students & $4.1 \%$ \\
\hline Healthcare workers & $3.9 \%$ \\
\hline Pregnant women & $2.5 \%$ \\
\hline Elderly & $5.5 \%$ \\
\hline Others & and other \\
\hline $\begin{array}{l}\text { *health care workers include midwife, dentist } \\
\text { health care workers. } \\
\text { * Others include herbalist, insurance company, teachers } \\
\text { and academic staff. } \\
\text { * Elderly: age more than 65 years old. }\end{array}$ \\
\hline
\end{tabular}




\begin{tabular}{|c|c|c|c|}
\hline Table 6. Range of Impact Factors and published articles. \\
\hline Impact factor Range & Number of Journals & Number of Articles published & Article/journal \\
\hline$<1$ & 14 & 45 & 3.2 \\
\hline $1-2$ & 21 & 35 & 1.7 \\
\hline $2-3$ & 13 & 26 & 2 \\
\hline $3-4$ & 8 & 14 & 1.8 \\
\hline $4-5$ & 3 & 4 & 1.3 \\
\hline$>5$ & 1 & 1 & 1 \\
\hline * The least Impact Factor was 0.034 and the most was 8.816. \\
\hline
\end{tabular}

fragmented and research studies are often designed and conducted without taking into account what is already known about rational medicines use problem or about successful intervention approaches. Proportion of planned interventions targeting the medicines use that were evaluated with methodologically adequate research designs was very low.

The focus of studies was on prescribing and utilization pattern, self-medication and adverse drug reaction. Such data especially in the field of utilization pattern are very important if policy planning is to take place in the future and for how to best prioritize medications. Several important aspects of medicine use such as prescribing of medicine based on Essential Medicine List/ formularies, implementation of clinical guideline, policy making and health insurance had not been studied enough. Despite the fact that the use of antibiotics has been increased over time in $\operatorname{Iran}^{11}$, but based on our search intervention to improve or rationalize them was not sufficient.

The Institute for Scientific Information (ISI: Philadelphia, USA) calculates the yearly Impact Factor for all journals included in the Science Citation Index, the Social Science Citation Index and the Arts and humanities Citation Index databases and publishes them in the Journal Citation Report (JCR). ${ }^{13}$ Most of our articles were published in journals with IF less than one. So considering the higher visibility of journals with impact factors, it would be worth to promote publication in journals with higher impact factors.

Analysis of articles showed that most of them were published in domestic journals; moreover nearly 50 of journals such as Iranian Journal of Medical Education and Tehran University Medical Journal were published in Persian language. As a result most of the researches were done in rational use of drugs have been local (small cities and small population) and publication of them in domestic journals with Persian language is easier than international journals.

Meanwhile among the topics, antibiotic resistance has the most citation but compare to other subjects such as prescribing pattern evaluation, the number of articles in this field is lower, and it indicates that topics such as antibiotic resistance have higher visibility and if we want to promote our scientometric indices we should be focus in this area. But our prescribing indicators still is not within WHO standards ${ }^{10}$, so we need more studies with better study designs to solve this problem and increase quality and citation of our articles.

Top main authors (publish more than 4 related articles) produce about $10 \%$ of all rational use of drugs publications. Other authors have been published less articles and it reflects lack of continuity in rational use of drugs -based research in Iran.

\section{CONCLUSIONS}

This study provides the first bibliographic and bibliometric analysis of publications in rational use of drugs in Iran. The finding presented here shows that despite increasing trends in publications patterns, still large gaps remain to be investigated. In addition, the results of this study are fundamental for research groups for the future rational use of drugs studies and also for policy makers in identifying evaluations and solutions for these existing gaps.

\section{CONFLICT OF INTEREST}

There is no conflict of interest to declare.

\begin{tabular}{|l|c|}
\hline \multicolumn{1}{|c|}{ Table 7. Distribution of articles and Impact Factors of journals. } \\
\hline \multicolumn{1}{|c|}{ Journal(Impact factor in 2011) } & Articles published \\
\hline Iranian Journal of Pharmaceutical Research(0.63) & 15 \\
\hline Eastern Mediterranean Health Journal & 15 \\
\hline Pharmacoepidemiology and drug safety(2.5) & 11 \\
\hline Iranian Journal of Medical Education & 10 \\
\hline Journal of Research in Medical sciences(0.45) & 8 \\
\hline Acta Medica Iranica & 8 \\
\hline Tehran University Medical Journal & 8 \\
\hline Iranian Journal of Public Health(0.37) & 7 \\
\hline Razi Journal of Medical Sciences & 7 \\
\hline Archives of Iranian Medicine & 6 \\
\hline Pharmacy World and Science(International Journal of Clinical Pharmacy)(1.2) & 5 \\
\hline Iranian Journal of Nursing Research & 5 \\
\hline Iranain Journal of Hematology- Oncology and Stem Cell Research & 5 \\
\hline Zahedan Journal of Research in Medical Sciences & 5 \\
\hline European Journal of Clinical Pharmacology(2.8) & 4 \\
\hline * Journals without Impact Factor were indexing in Pubmed, Scopus, Ebsco, Google Scholar and some Persian \\
sites such as Mag Iran, SID and Iran Medex. & \\
\hline
\end{tabular}




\begin{tabular}{|c|c|c|c|l|}
\hline Table 8. Total documents and citation analysis of ten First authors. \\
\hline First Authors & $\begin{array}{c}\text { Total RUD } \\
\text { documents\# }\end{array}$ & $\begin{array}{c}\text { Total citation of } \\
\text { most cited topics* }\end{array}$ & $\begin{array}{c}\text { Average citation } \\
\text { per year* }\end{array}$ & Most cited topic \\
\hline 1 & 28 & 37 & 2.6 & Adverse drug reaction \\
\hline 2 & 11 & 10 & 2 & Adverse drug reaction \\
\hline 3 & 9 & 6 & 0.8 & Guideline adherence \\
\hline 4 & 9 & 2 & 0.5 & Adverse drug reaction \\
\hline 5 & 8 & 11 & 1.8 & Adverse drug reaction \\
\hline 6 & 8 & 3 & 0.6 & Prescribing pattern evaluation \\
\hline 7 & 7 & 8 & 4 & Cost analysis \\
\hline 8 & 6 & 10 & 1.1 & Access and prescribing pattern \\
\hline 9 & 6 & 5 & 1 & Educational intervention \\
\hline 10 & 5 & 9 & 2.2 & Adverse drug reaction \\
\hline
\end{tabular}

\begin{tabular}{|l|c|c|c|c|}
\hline \multicolumn{1}{|c|}{ Table 9. Total citations and ratios of most studied topics. } \\
\hline $\begin{array}{c}\text { Total number of } \\
\text { articles }\end{array}$ & $\begin{array}{c}\text { Total } \\
\text { citations }\end{array}$ & $\begin{array}{c}\text { Ratio(total citation/total number of } \\
\text { articles) }\end{array}$ & $\begin{array}{c}\text { Range of } \\
\text { citations }\end{array}$ \\
\hline Antimicrobial resistance & 38 & 358 & 9.4 & $(0-109)$ \\
\hline Adverse drug reaction & 41 & 233 & 2.6 & $(0-71)$ \\
\hline $\begin{array}{l}\text { Prescribing and dispensing } \\
\text { pattern }\end{array}$ & 68 & 198 & 2.47 & $(0-23)$ \\
\hline Medication error & 30 & 105 & 3.5 & $(0-21)$ \\
\hline Self-medication & 51 & 71 & 1.3 & $(0-10)$ \\
\hline Prescription evaluation & 33 & 45 & 1.3 & $(0-18)$ \\
\hline *Based on Google Scholar Citations.
\end{tabular}

\section{References}

1. Laing R, Waning B, Gray A, Ford N, 't Hoen E. 25 years of the WHO essential medicines lists: progress and challenges. Lancet. 2003;361(9370):1723-9.

2. Promoting rational use of medicines: Core components: WHO policy perspectives on medicines, Number 5. Geneva, World Health Organization, 2002.

3. Otoom SA, Sequeira RP. Health care providers' perceptions of the problems and causes of irrational use of drugs in two Middle East countries. Int J Clin Pract. 2006;60(5):565-70.

4. Laing R, Hogerzeil H, Ross-Degnan D. Ten recommendations to improve use of medicines in developing countries. Health Policy Plan. 2001;16(1):13-20.

5. Kermer M. Pharmaceuticals and developing countries. J Econ Perspect. 2002;16(4):67-90.

6. Progress in the rational use of medicines. World Health Assembly resolution WHA 60.16. Geneva. World Health Organization, 2007.

7. Hardon AP, le Grand A. Pharmaceuticals in communities. Practices, public health consequences and intervention strategies. Bulletin 330. Royal Tropical Institute, The Netherlands, 1993.

8. Dinarvand R. New National Drug policy in Iran leading to expanded pharmaceutical market and extended access of public to medicines. Iranian J Publ Health 2009; 38(1):158-61.

9. Cheraghali AM, Nikfar S, Behmanesh Y, Rahimi V, Habibipour F, Tirdad R, Asadi A, Bahrami A. Evaluation of availability, accessibility and prescribing pattern of medicines in the Islamic Republic of Iran. East Mediterr Health J. 2004;10(3):406-15.

10. Soleymani F, Valadkhani M, Dinarvand R. Challenges and achievements of promoting rational use of drugs in Iran. Iranian J Publ Health 2009; 38(1):166-8.

11. Abdollahiasl A, kebriaeezadeh A, Nikfar S, Farshchi A, Abdollahi M. Patterns of antibiotic consumption in Iran during 2000-2009. Int J Antimicrob Agents. 2011;37(5):489-90. doi: 10.1016/j.ijantimicag.2011.01.022.

12. Mesgarpour B, Etemadi A, Fotouhi A, Kebriaeezadeh A, Younesian M. The Trend of Pharmaceutical Research in Iran Compared to Middle East and North Africa: A Scientometrics Study. Health Inf Manag 2009;6(2):151.

13. ISI Web of Knowledge.Journal Citation Reports. Available at: http://www. http://diglib.tums.ac.ir/. (Accessed 14-072012). 